JURNAL KETAHANAN NASIONAL

P-ISSN: 0853-9340, e-ISSN: 2527-9688

Online sejak 28 Desember 2015 di: http://jurnal.ugm.ac.id/JKN

VOLUME 22

No. 2, 25 Agustus 2016

Halaman 217-236

\title{
PERAN KELOMPOK BATIK TULIS GIRILOYO DALAM MENDUKUNG KETAHANAN EKONOMI KELUARGA (Studi Di Dusun Giriloyo, Desa Wukirsari, Kecamatan Imogiri, Kabupaten Bantul, Daerah Istimewa Yogyakarta)
}

\author{
Arif Nursaid \\ Kodam II/ Sriwijaya Palembang Sumatera Selatan \\ Email: ayipnoer@gmail.com \\ Armaidy Armawi \\ Fakultas Filsafat Universitas Gadjah Mada
}

\begin{abstract}
This research aimed to determined the activities and productivity of batik tulis Sekar Arum group in Hamlet Giriloyo. It was the role in contributing to the economic resilience of families in the hamlet Giriloyo, Wukirsari village, Imogiri, Bantul, Special Region of Yogyakarta, and constraints and efforts in the field.

This research used mixed methods research. Mixed Methods Research in the first stage used a qualitative study with a structured interview, observation and literature which were then processed with using a quantitative assay. Quantitative assay in this study used coefficient determination test, $t$ test, and test multiple linear regression analysis. The data used were primary data. Primary data in this study were obtained from in-depth interviews and questionnaires. This study used several indicators to measured the economic resilience of the family. The indicators used were derived from the Central Bureau of Statistics, Standard UMK, Regent Regulation No. 21 A of 2007 on Poverty Indicators Bantul, and the World Bank.

The results showed that the family group Sekar Arum was not classified in poor families. Family members of the group Sekar Arum had a strong family economic resilience. Obstacles encountered in the form of batik product marketing system was not optimal, financial reporting system that was less professional, less supportive of accessibility, availability of communications networks were minimal, and lack of awareness and interest in the younger generation to made batik. Recommendations in the form of optimization various batik products Giriloyo, mentoring system making financial reports, establishing communication with various parties to the improvement of accessibility, establishing intense communication with the provider and the county government, and cooperating with the government on education and the regeneration process.
\end{abstract}

Keywords: Role, Batik Tulis Group, Family Economic Resilience

\begin{abstract}
ABSTRAK
Penelitian ini bertujuan untuk mengetahui aktivitas dan produktivitas kelompok batik tulis Sekar Arum di Dusun Giriloyo, dalam memberikan kontribusi pada ketahanan ekonomi keluarga di Dusun Giriloyo, Desa Wukirsari, Kecamatan Imogiri, Kabupaten Bantul, Daerah Istimewa Yogyakarta. Di samping itu, penelitian ini juga bertujuan untuk mengetahui kendala-kendala yang dihadapi kelompok batik tulis Sekar Arum di Dusun Giriloyo dan upayaupaya yang dilakukan untuk mengatasi kendala-kendala tersebut di lapangan.
\end{abstract}


Penelitian ini bersifat mixed methods research. Mixed Methods Research pada tahap pertama menggunakan penelitian kualitatif dengan menggunakan wawancara secara terstruktur, observasi dan studi pustaka yang selanjutnya diproses menggunakan uji kuantitatif. Uji kuantitatif pada penelitian ini menggunakan uji koefisien determinasi, uji t, dan uji analisis regresi linear berganda. Data yang digunakan yaitu data primer. Data primer dalam penelitian ini diperoleh dari hasil wawancara mendalam dan menyebar kuesioner. Penelitian ini menggunakan beberapa indikator dalam mengukur ketahanan ekonomi keluarga. Indikator yang digunakan yaitu berasal dari Badan Pusat Statistik, Standar UMK, Peraturan Bupati No 21 A Tahun 2007 tentang Indikator Kemiskinan Kabupaten Bantul., dan Bank Dunia.

Hasil penelitian menunjukkan bahwa keluarga kelompok Sekar Arum tidak terklasifikasi dalam keluarga miskin. Keluarga anggota kelompok Sekar Arum memiliki ketahanan ekonomi keluarga yang tangguh. Kendala yang dihadapi berupa sistem pemasaran produk batik tulis yang belum optimal, sistem laporan keuangan yang kurang profesional, aksesibilitas yang kurang mendukung, ketersediaan jaringan komunikasi yang sangat minim, dan kurangnya kesadaran dan ketertarikan generasi muda untuk membatik. Rekomendasi berupa pengoptimalan pemasaran berbagai produk batik tulis Giriloyo, pendampingan pembuatan sistem laporan keuangan, menjalin komunikasi dengan berbagai pihak untuk perbaikan aksesibilitas, menjalin komunikasi intens dengan provider dan pemerintah kabupaten, dan bekerjasama dengan pemerintah untuk pendidikan dan proses regenerasi.

Kata Kunci: Peran, Kelompok Batik Tulis, Ketahanan Ekonomi Keluarga

\section{PENGANTAR}

Batik adalah suatu hasil karya yang tidak asing lagi bagi masyarakat Indonesia. Di berbagai wilayah Indonesia banyak ditemui daerah-daerah pengrajin batik. Setiap daerah pembatikan mempunyai keunikan dan kekhasan tersendiri, baik dalam ragam hias maupun tata warnanya. Seiring perkembangan zaman, menurut Sudijono (2006) dalam "Pasang Surut Batik Tradisional Bantul, Studi Kasus Batik Tulis Imogiri Tahun 19701998", budaya batik tulis semakin terkikis karena semakin murahnya batik yang datang dari luar negeri dan semakin berkembangnya batik cetak yang bisa memenuhi kebutuhan masyarakat akan kebutuhan batik secara cepat. Batik berasal dari bahasa jawa "mbatik", yaitu mbat yang merupakan kependekan dari ngembat atau melontarkan dan tik yang merupakan kependekan dari titik sehingga batik diartikan sebagai melemparkan titik berkali-kali dalam selembar kain (Tim Sanggar Batik Barcode, 2010: 3). Setiap daerah tentu memiliki kekhasan batiknya masing-masing, begitu pula dengan batik tulis Giriloyo. Batik tulis Giriloyo memiliki ciri khas di model, motif dan tentu saja pewarnaan. Biasanya, motif batik yang digunakan mengandung makna tersendiri.

Satu dusun di Yogyakarta yang sampai saat ini melestarikan batik khususnya batik tulis, yaitu Dusun Giriloyo di Kabupaten Bantul. Pemerintah Kabupaten Bantul telah mendokumentasikan 53 motif batik asli Bantul. Meskipun perlu diberi catatan bahwa dari 53 motif batik asli Bantul tersebut ada beberapa motif batik yang tidak mencerminkan atau berkiblat pada keraton karena menggunakan warna yang tidak lumrah, seperti motif irian yang menggunakan warna dasar oranye. Dengan demikian, Batik Bantul yang ada di buku tersebut lebih dimaknai sebagai batik yang dibuat oleh seniman yang tinggal di Bantul. Penelitian ini tidak membicarakan lebih lanjut perdebatan makna batik sebagai corak, namun lebih fokus melihat peran kelompok batik tulis dalam mendukung ketahanan ekonomi keluarga.

Terdapat empat kelompok batik tulis di Dusun Giriloyo yang mandiri yaitu 
kelompok Sekar Arum, Sungging Tumpuk, Sida Mukti dan Sekar Kedaton. Sunarti (2003:3) menyebutkan bahwa dalam ketahanan ekonomi keluarga terdapat beberapa komponen input meliputi sumber daya yang dimiliki keluarga baik secara fisik, maupun non fisik mental spiritual. Sumber daya fisik material diukur dari kemampuan ekonomi sebuah pendapatan perkapita, aset keluarga dan pengeluaran perkapita. Tulisan ini bertujuan Untuk mengetahui gambaran Kelompok Batik Tulis Sekar Arum di Dusun Giriloyo, Desa Wukirsari, Kecamatan Imogiri, Kabupaten Bantul., peran, kendala yang dihadapi, dan upaya mengatasi kendala yang dihadapi pada Kelompok Batik Tulis Sekar Arum di Dusun Giriloyo, Desa Wukirsari, Kecamatan Imogiri, Kabupaten Bantul.

Kelompok batik Sekar Arum jika tidak ada permintaan maka pengrajin tidak akan berproduksi. Jika tidak ada produksi maka tidak ada orang yang bekerja di batik. Jika tidak ada yang bekerja maka mereka tidak akan sejahtera. Jika tidak sejahtera dengan usaha batik maka ia akan menghentikan usaha batiknya dan beralih ke bidang lain. Jika tidak ada yang bekerja di sektor batik maka batik akan punah, padahal batik merupakan warisan budaya yang tak ternilai harganya. Oleh karena itu dibutuhkan intervensi pasar guna memperbanyak permintaan akan batik sehingga pengrajin sejahtera. Namun, jika pasar terbuka lebar, tetapi tidak ada produsen batik dapat menimbulkan masalah baru karena perlu mendatangkan barang dari daerah lain. Oleh karena itu, selain membuka pasar diperlukan upaya peningkatan ketrampilan sumber daya manusia Kabupaten Bantul dalam usaha batik sehingga tersedia tenaga kerja dan calon pengusaha-pengusaha baru. Lebih lanjut, diungkapkan Sunarti (2003: 3) bahwa dalam ketahanan ekonomi keluarga terdapat beberapa komponen input meliputi sumber daya yang dimiliki keluarga baik secara fisik, maupun non fisik mental spiritual. Sumber daya fisik material diukur dari kemampuan ekonomi sebuah pendapatan perkapita, aset keluarga dan pengeluaran perkapita. Sebuah keluarga yang telah terpenuhi ketahanan ekonomi, maka dapat dilihat dari indikator pendapatan per kapita dan aset per keluarga serta pengeluarannya per kapita.Dengan mengaitkan persoalan di atas, peneliti secara spesifik menganalisis apakah ada peran kelompok Batik Tulis dalam mendukung ketahanan ekonomi keluarga pengrajinnya, khususnya pada kelompok Sekar Arum di Dusun Giriloyo, Desa Wukirsari Kecamatan Imogiri, Kabupaten Bantul, provinsi DIY. Peneliti juga mencoba menggali kendalakendala yang dihadapi oleh kelompok Batik Tulis di Dusun Giriloyo, Desa Wukirsari, Kecamatan Imogiri, Kabupaten Bantul, Provinsi DIY dalam mendukung ketahanan ekonomi keluarga. Kemudian melakukan pendalaman dalam berbagai upaya yang dilakukan oleh Kelompok Batik Tulis di Dusun Giriloyo, Desa Wukirsari, Kecamatan Imogiri, Kabupaten Bantul, Provinsi DIY untuk mendukung ketahanan ekonomi keluarganya. Serta mengetahui pengaruh peran Kelompok Batik Tulis Sekar Arum terhadap ketahanan ekonomi keluarga di Dusun Giriloyo, Desa Wukirsari, Kecamatan Imogiri, Kabupaten Bantul. Jenis penelitian ini adalah mixed methods research. Creswell (2009) menjabarkan mixed methods research sebagai suatu desain penelitian yang didasari asumsi filosofis sebagaimana metoda inkuiri. Mixed methods research juga disebut sebagai 
sebuah metode yang memberikan asumsi filosofis dalam menunjukkan arah atau memberi petunjuk cara pengumpulan data dan menganalisis data serta perpaduan pendekatan kuantitatif dan kualitatif melalui beberapa fase proses penelitian. Sebagai sebuah metoda, mixed methods research berfokus pada pengumpulan dan analisis data serta memadukan antara data kuantitatif dan data kualitatif baik dalam single study (penelitian tunggal) maupun series study (penelitian berseri).

Creswell (2009) mengklasifikasikan terdapat dua model utama metode kombinasi yaitu model sequential (kombinasi berurutan), dan model concurrent (kombinasi campuran). Model urutan (sequential) ada dua yaitu model urutan pembuktian (sequential explanatory) dan model urutan penemuan (sequential exploratory). Model concurrent (campuran) ada dua yaitu, model concurrent triangulation (campuran kuantitatif dan kualitatif secara berimbang) dan concurrent embedded (campuran penguatan/ metode kedua memperkuat metode pertama).

Penelitian ini menggunakan sequential exploratory, yang menurut Creswell (2009) dapat disamakan dengan metode sequential explanatory, hanya dibalik, dimana pada metode ini pada tahap awal menggunakan metode kualitatif dan tahap berikutnya menggunakan metode kuantitatif. Bobot metode lebih pada metode tahap pertama yaitu metode kualitatif dan selanjutnya dilengkapi dengan metode kuantitatif. Metode kualitatif yang digunakan dalam penelitian ini yaitu dengan indeph interview. Sedangkan metode kuantitatif peneliti melakukan uji analisis regresi pada pendapatan anggota kelompok batik Sekar
Arum terhadap standar hidup layak. Metode kuantitatif tersebut digunakan sebagai kajian yang memperkuat argumen kualitatif yang telah dilakukan sebelumnya.

Kombinasi data kedua metode bersifat connecting (menyambung) hasil penelitian tahap pertama (hasil penelitian kualitatif) dan tahap berikutnya (hasil penelitian kuantitatif). Populasi yang digunakan dalam penelitian ini yaitu kelompok batik yang berada di Dusun Giriloyo, Desa Wukirsari, Kabupaten Bantul. Sampel dipilih dengan menggunakan purposive sampling. Terdapat beberapa kriteria yang digunakan dalam penentuan sampel. Kriteria tersebut yaitu kelompok batik berada di Dusun Giriloyo, kelompok batik memiliki anggota yang aktif lebih dari 25 orang, kelompok batik selalu aktif dalam setiap kegiatan produksi batik. Berdasarkan kriteria tersebut sampel dalam penelitian ini yaitu kelompok batik Sekar Arum. Kelompok batik Sekar Arum dipilih berdasarkan tingkat keaktifan dalam produksi batik serta keikutsertaan dalam berbagai kegiatan berbasis Usaha Mikro, Kecil, dan Menengah (UMKM), jumlah anggota yang aktif berjumlah 30 orang. Berdasarkan jumlah anggota tersebut telah memenuhi jumlah sampel minimal dalam penelitian kuantitatif.

Hasil penelitian yang diharapkan dalam penelitian ini yaitu berupa pemahaman kontribusi sistem produksi ekonomi berbasis kelompok akan lebih bertahan atau berkelanjutan dalam persaingan bisnis. Produksi tersebut nantinya akan sedikit terbantu untuk bersaing dengan produsen besar berbasis produksi massal. Beberapa hal yang ditemukan dalam penelitian ini yaitu bahwa industri rumah tangga berbasis Usaha Mikro Kecil dan Menengah yang 
memiliki modal terbatas akan lebih bertahan dan memiliki ketahanan yang cukup tangguh dalam persaingan bisnis. Sedangkan kontribusi dalam penelitian ini yaitu dapat diketahuinya bahwa industri rumah tangga berbasis UMKM akan lebih bertahan dan berkelanjutan apabila dibangun dalam bentuk kelompok. Hal ini difungsikan untuk mampu bersaing dengan produsen berbasis industri menengah atau industri besar.

\section{PEMBAHASAN}

\section{Karakteristik Sosial-Ekonomi Pengrajin Batik}

Keanggotaan kelompok batik tulis Dusun Giriloyo khususnya Sekar Arum terdiri dari beberapa orang. Anggota kelompok batik Sekar Arum dalam penelitian ini dijadikan responden oleh peneliti. Keanggotaan kelompok batik tulis Dusun Giriloyo Sekar Arum berdasar usia ditunjukkan oleh tabel 1.

Tabel 1.

Keanggotaan Berdasarkan Usia

\begin{tabular}{cccc}
\hline No & \multicolumn{1}{c}{ Usia } & Jumlah & Persentase \\
\hline 1 & $<30$ Tahun & 4 & 13 \\
2 & 30 tahun -50 tahun & 15 & 50 \\
3 & $>50$ tahun & 11 & 37 \\
\hline & Jumlah & 30 & 100 \\
\hline
\end{tabular}

Sumber: Data Primer, 2016

Tabel 1 menunjukkan bahwa pengrajin batik tulis Dusun Giriloyo yang memiliki usia di bawah 30 tahun sebanyak 4 orang atau sebesar 13 persen yang berusia 30 hingga 50 tahun sebanyak 15 orang atau 50 persen, Pengrajin pada rentang usia tersebut mayoritas karena pada dasarnya bergabung untuk mendapatkan tambahan pendapatan keluarga. Sedangkan pengrajin batik tulis Dusun Giriloyo yaitu ibu-ibu yang berusia di atas 50 tahun sebanyak 11 orang atau 37 persen. Perempuan pada usia tersebut mengisi hari tua untuk dapat menghasilkan batik dan untuk ikut membantu memenuhi kebutuhan keluarga.

Keanggotaan kelompok batik tulis Dusun Giriloyo Sekar Arum berdasar jenis kelamin ditunjukkan oleh tabel 2.

Tabel 2.

Keanggotaan Berdasarkan Jenis Kelamin

\begin{tabular}{clcc}
\hline No & Jenis Kelamin & Jumlah & Persentase \\
\hline 1 & Laki-laki & 1 & $3 \%$ \\
2 & Perempuan & 29 & $97 \%$ \\
\hline & Jumlah & 30 & $100 \%$ \\
\hline
\end{tabular}

Sumber : Data Primer, 2016

Tabel 2 menunjukkan bahwa anggota kelompok batik tulis Dusun Giriloyo Sekar Arum mayoritas beranggotakan perempuan yaitu sebanyak 29 orang atau 97 persen. Sedangkan keterlibatan laki-laki hanya satu orang atau 3 persen. Keterlibatan laki-laki yang minim dalam hal ini karena di daerah tersebut mayoritas laki-laki telah bekerja sebagai petani, buruh pabrik, buruh bangunan, pegawai swasta, pegawai negeri sipil. Keterlibatan laki-laki dalam kelompok Sekar Arum berfungsi dan bertugas sebagai ketua kelompok, yaitu menjalin relasi, membangun jaringan dan komunikasi dengan instansi, lembaga atau pihak swasta. Pembangunan jaringan tersebut berfungsi sebagai sarana pengembangan serta pemasaran produk batik tulis Dusun Giriloyo Sekar Arum. Peran dan fungsi anggota kelompok perempuan lebih condong pada aspek produksi, karena pada dasarnya perempuan memiliki ketelatenan dan ketelitian yang tinggi.

Keanggotaan kelompok batik tulis Dusun Giriloyo Sekar Arum berdasar tingkat pendidikan ditunjukkan oleh tabel 3. 
Tabel 3.

Keanggotaan Berdasarkan Tingkat Pendidikan

\begin{tabular}{clcc}
\hline No & \multicolumn{1}{c}{ Tingkat Pendidikan } & Jumlah & Persentase \\
\hline 1 & Tidak tamat Sekolah Dasar & 0 & 0 \\
2 & Tamat Sekolah Dasar/ Sekolah Rakyat (SR) & 10 & 33 \\
3 & Tamat Sekolah Menengah Pertama (SMP) & 15 & 50 \\
4 & Tamat Sekolah Menengah Atas (SMA) & 5 & 17 \\
5 & Tamat Diploma III (D III) & 0 & 0 \\
6 & Tamat Sarjana (S1) & 0 & 0 \\
\hline & Jumlah & 30 & 100 \\
\hline
\end{tabular}

Sumber : Data Primer, 2016

Tabel 3 menunjukkan bahwa tingkat pendidikan terakhir pengrajin batik Dusun Giriloyo kelompok Sekar Arum didominasi lulusan Sekolah Menengah Pertama (SMP) sebanyak 15 orang atau 50 persen, Sekolah Rakyat (SR) atau setara Sekolah Dasar (SD) sebanyak 10 orang atau 33 persen, Tingkat pendidikan tertinggi pengrajin batik Dusun Giriloyo kelompok Sekar Arum yaitu Sekolah Menengah Atas (SMA) sebanyak 5 orang atau 17 persen. Sedang yang tidak tamat Sekolah Dasar, lulusan Diploma III, dan lulusan Perguruan Tingga adalah tidak ada atau 0 persen.

Anggota kelompok Sekar Arum sebagian memiliki anak berpendidikan Diploma III atau Mahasiswa S-1 dan juga lulusan Perguruan Tinggi. Anak pengrajin batik Dusun Giriloyo yang berpendidikan tinggi lebih cenderung memilih bekerja di kota dan memilih menjadi karyawan. Hal ini yang menjadi dilema orang tua dan juga keberlangsungan batik tulis Dusun Giriloyo.

Pembatik di Dusun Giriloyo telah menjadi pembatik sudah lama. Pekerjaan ini telah menjadi pekerjaan turun temurun. Hal ini didasarkan karena Dusun Giriloyo secara historis menjadi daerah pembatik.

Tabel 4 menjelaskan bahwa anggota kelompok batik Sekar Arum yang memiliki
Tabel 4.

Lama Menjalani Profesi menjadi Pembatik

\begin{tabular}{clc}
\hline No & Lama Membatik & Jumlah \\
\hline 1 & $<20$ Tahun & 5 \\
2 & $21-40$ Tahun & 13 \\
3 & $>41 \quad$ & 12 \\
\hline \multicolumn{2}{c}{ Jumlah } & $\mathbf{3 0}$ \\
\hline
\end{tabular}

Sumber: Data Primer, 2016

anggota sebanyak 30 orang mayoritas menjadi pembatik selama 21-40 tahun. Anggota yang menjalani profesi sebagai pembatik selama lebih dari 41 tahun sebanyak 12 anggota. Pembatik yang menjalani profesi sebagai pembatik selama kurang dari 20 tahun sebanyak 5 orang. Berdasarkan tabel di atas mengindikasikan bahwa sebagian besar penduduk yang termasuk dalam anggota kelompok batik Sekar Arum mayoritas menghabiskan waktu berprofesi sebagai pembatik.

\section{Peran Kelompok Batik Tulis Sekar Arum}

Kelompok batik Sekar Arum dalam implementasinya memiliki 2 (dua) beberapa peran.

Pertama, kelompok batik sebagai jembatan kesejahteraan. Produk batik Sekar Arum menggunakan bahan kain primisima atau prima mesres dengan pewarnaan alami maupun sintetis. Produksi kain batik kelompok 
ini dalam satu bulan sekitar 34 pieces sedangkan untuk baju antara 50 - 70 potong. Selain itu, Sekar Arum juga memproduksi selendang, syal, sajadah taplak dan produk batik lain sesuai pesanan pelanggan. Berkaitan dengan omset dan pendapatan, sebagai Ketua kelompok yaitu Nur Ahmadi menjelaskan bahwa omset penjualan bahan batik, kain batik, serta produk batik jadi berupa pakaian cukup besar. Harga bahan baku primisima per potongnya Rp. 40.000 dan upah jasa membatik Rp. Rp. 70.000 - Rp. 150.0000 per potongnya. Mengingat semua produknya merupakan batik tulis, harganya di atas harga batik pada umumnya. Kain batik tulis maupun baju dijual dengan harga mulai Rp. 175.000 hingga Rp. 800.000 tergantung pada motif dan pewarnaan. Untuk ongkos jahit, Nur Ahmadi mematok harga mulai Rp. 35.000 per potong. Omset usaha kelompok ini sekitar $5-7$ juta per bulan dari penjualan kain dan omset sekitar Rp. 11 juta untuk produk pakaian jadi. Rata-rata pendapatan sebulan untuk penjualan pakaian dan kain batik sekitar Rp. 16 jutaan.

Kedua, kelompok batik tulis di Giriloyo sebagai obyek wisata alternatif dan tempat pendidikan. Selain hal tersebut, beberapa paket wisata telah disiapkan sebagai sarana promosi serta pengenalan batik tulis Giriloyo, khususnya Sekar Arum. Paket wisata batik di Yogyakarta menawarkan pengalaman untuk "Belajar Membatik" menciptakan hasil karya batik tulis dengan didampingi para pengrajin batik Yogyakarta di Sentra Batik Tulis Giriloyo. Para pendamping akan mengajari dan memandu secara sederhana tentang bagaimana proses produksi batik tulis yang benar, mulai dari tahap awal sampai menghasilkan hasil karya kain batik tulis khas Yogyakarta. Di Dusun Giriloyo, juga memiliki kesempatan untuk mengunjungi rumah batik Yogyakarta yang memproduksi batik tulis khas Yogyakarta.

\section{Masyarakat Giriloyo Menghadapi Perkembangan Pariwisata}

Masyarakat merupakan salah satu unsur pokok pariwisata di samping obyek wisata, sarana dan prasarana wisata, serta tata laksana kegiatan wisata. Hal tersebut juga berlaku pada kehadiran Desa Wisata Sentra Kerajinan Batik Tulis Giriloyo. Kehadiran desa wisata ini dinilai memiliki daya tarik wisatawan khususnya terhadap kegiatan budaya masyarakatnya. Interaksi yang terjadi di desa wisata ini dilakukan secara langsung antara masyarakat Giriloyo dengan para pengunjung/wisatawan, mulai dari penyambutan kehadiran hingga pelayanan wisata.

Usaha Pengembangan Desa Wisata Sentra Kerajinan Batik Tulis Giriloyo memiliki beberapa hal yang perlu dipahami masyarakat mengenai berbagai jenis dan kualitas pelayanan yang dibutuhkan oleh para wisatawan. Informasi tersebut tentu sudah disampaikan oleh pemerintah dengan diadakannya berbagai penyuluhan kepada masyarakat Giriloyo sebelum Dusun Giriloyo ini resmi dicanangkan sebagai desa wisata. Namun fenomena yang terjadi saat ini justru masyarakat Giriloyo dinilai kurang mempertimbangkan kualitas pelayanan yang disebabkan karena minimnya sarana dan prasarana dari pemerintah. Jika hal tersebut dibiarkan, tentu akan mengancam keberlangsungan aktivitas wisata yang ada di Desa Wisata Sentra Kerajinan Batik Tulis Giriloyo ini. Peran serta masyarakat dalam pariwisata sangatlah penting guna menciptakan iklim pariwisata di kalangan masyarakat secara aktif. Oleh karena itu perlu 
dilakukan koordinasi untuk mendorong peran serta masyarakat dengan berbagai cara.

Pembangunan desa wisata tidak lepas dari peran serta masyarakat. Oleh sebab itu diperlukan adanya situasi dan kondisi masyarakat yang memiliki pola berpikir yang sadar wisata. Penerapan sikap sadar wisata diharapkan akan mengembangkan pemahaman dan pengertian yang proporsional di antara berbagai pihak, sehingga pada gilirannya akan mendorong masyarakat untuk berperan serta dalam pariwisata. Pemda Bantul melalui Dinas Pariwisata telah melakukan penyuluhan kepada para pengrajin dan masyarakat di kawasan Desa Wisata Sentra Kerajinan Batik Tulis Giriloyo tentang perlunya sikap sadar wisata. Masyarakat akan tertarik untuk berperan apabila telah memahami bahwa mereka akan mendapatkan manfaat yang positif. Citra dan produk wisata merupakan tolok ukur kualitas destinasi pariwisata. Kesadaran masyarakat terhadap nilai wisata dapat mempengaruhi usaha masyarakat untuk memperbaiki dan meningkatkan citra dan produk wisata.

Hubungan kerjasama dan koordinasi yang dilakukan mencakup kegiatan kerjasama dan koordinasi lintas sektoral, kewenangan lintas sektoral, dan menggalang peran serta masyarakat. Masyarakat bisa berperan serta apabila: memiliki motivasi yang kuat; memiliki kemauan dan kemampuan untuk berperan; dan diberi kesempatan untuk ikut berperan serta. Usaha peningkatan kualitas produksi kerajinan batik tulis dan promosi hingga ke luar daerah perlu melibatkan peran serta masyarakat di Dusun Giriloyo dalam hal pemberian pelayanan kepada para pengunjung atau wisatawan agar tercipta citra yang baik akan obyek wisata. Pelayanan masyarakat kepada pengunjung atau wisatawan ini tercermin pada sikap mereka menyambut wisatawan saat mengamati koleksi, belajar membatik, membeli produk kerajinan, dan lain-lain.

\section{Kendala-kendala Kelompok Batik Tulis Sekar Arum}

Beberapa kendala dan permasalahan yang dialami oleh kelompok batik tulis Sekar Arum adalah sebagai berikut.

Pertama, sistem pemasaran produk batik tulis yang belum optimal. Unsurunsur pemasaran yang terdapat di lapangan adalah (1). Kelompok batik tulis tersebut hanya memiliki produk berupa kain batik dan pakaian jadi. Pengembangan produk tidak dapat berkembang ke berbagai macam inovasi. (2). Harga kain batik tulis yang diproduksi oleh kelompok batik tulis Sekar Arum jika dibandingkan dengan harga kain batik di pasar, dapat diklasifikasikan ke dalam harga yang cukup tinggi. Harga yang cukp tinggi didasari oleh jenis kain yang dipakai untuk membatik, serta jenis pewarnaan yang memerlukan bahan baku yang langka. Harga yang kurang berkompetisi dengan harga batik di pasar membuat kain batik tulis kelompok Sekar Arum memiliki segmetasi pasar yang berbeda. (3). Sistem distribusi yang masih konvensional, dalam arti masih sebatas menggunakan jasa pengiriman barang yang disediakan oleh beberapa perusahaan jasa. Sistem pendistribusian masih terkendala dengan sistem komunikasi. Pemesanan produk hanya berdasarkan jumlah persediaan barang di suplier batik di beberapa kota serta berdasarkan pesanan. (4). Promosi yang dilakukan oleh kelompok batik tulis Sekar Arum melalui berbagai cara. Promosi melalui iklan di berbagai media tekstil, melalui website DisPerinDaKop Kabupaten 
Bantul, dan melalui berbaagai pameran yang diselenggarakan berbagai pihak seperti swasta, pemerintah Kabupaten Bantul, Pemerintah Daerah Istimewa Yogyakarta, ataupun Kementerian telah diikuti. Namun demikian, promosi melalui media sosial dan website masih terkendala oleh jaringan internet yang sangat buruk di daerah Giriloyo. Sedangkan hasil pameran yang telah diikuti kelompok batik tulis Sekar Arum terkendala dengan jaringan seluler yang minim. Hal ini yang menyebabkan promosi kurang maksimal.

Kedua, sistem laporan keuangan yang kurang profesional. Laporan keuangan merupakan salah satu hal yang penting dalam membangun sebuah usaha. Standar Akuntansi Keuangan menegaskan bahwa laporan keuangan yang dibuat oleh manajemen secara berkala setiap periode mempunyai tujuan: (1). Memberikan informasi tentang posisi keuangan, kinerja (prestasi) dan aliran kas perusahaan yang berguna bagi pemakai dalam rangka pengambilan keputusan. (2). Sebagai sarana pertanggungjawaban (responsibility) manajemen atas pengelolaan perusahaan atau pengusaha selama ini.

Kelompok batik tulis Sekar Arum tidak memiliki catatan atau laporan keuangan yang sesuai standart akuntansi, dan hanya memiliki catatan keuangan barang keluar atau yang terjual. Hal ini menjadikan suatu permasalahan dalam menghimpun informasi mengenai kemajuan ataupun kemunduran usaha bersama kelompok batik tulis Sekar Arum. Laporan keuangan yang tidak sesuai dengan standart berimbas pada sulitnya kelompok batik tulis Sekar Arum dalam mengadakan kredit usaha yang diselenggarakan oleh penyedia jasa keuangan.

Ketiga, aksesibilitas yang kurang mendukung. Kecamatan Imogiri merupakan wilayah yang berada di Kabupaten Bantul, tepatnya di bagian selatan dari Kabupaten Bantul. Kecamatan Imogiri terdiri dari beberapa desa yang salah satunya adalah Desa Wukirsari. Desa Wukirsari tersebut merupakan desa yang terletak di sebelah makam raja Mataram. Sedangkan Dusun Giriloyo merupakan dusun yang terdapat di bagian atas dari Desa Wukirsari. Sarana transportasi umum tidak tersedia untuk menjangkau Desa Wukirsari, juga untuk menjangkau Dusun Giriloyo. Ketidaktersediaan sarana transportasi umum ke Dusun Giriloyo dikarenakan lokasi dusun tersebut yang memang tidak mudah dijangkau, termasuk oleh bus pariwisata. Kondisi jalan di Dusun Giriloyo hanya dapat dipakai untuk selajur mobil. Selain itu, kondisi geografis Dusun Giriloyo yang berada di ketinggian juga menjadi faktor ketidaktersediaan sarana transportasi umum. Kondisi jalan menuju Dusun Giriloyo kurang baik walaupun sudah diaspal, di sepanjang jalan Dusun Giriloyo aspal telah terkelupas, sehingga kondisi tersebut membuat jalan berlubang dan tidak rata.

Keempat, ketersediaan jaringan komunikasi yang sangat minim. Kondisi geografis lokasi penelitian merupakan daerah yang terletak di daerah peguunngan Imogiri. Sebagian wilayah Dusun Giriloyo berada di sekitar lembah pegunungan. Selain itu keterbatasan akses jalan membuat perusahaan penyedia jasa telekomunikasi kurang berminat untuk melakukan pembuatan tower telekomunikasi di daerah tersebut. Hal ini juga terjadi pada perusahaan milik pemerintah yang bergerak di bidang telekomunikasi. Ketidakterjangkauan akses telekomunikasi ini menjadikan Dusun Giriloyo menjadi daerah terpencil dengan minim informasi. 
Keterbatasan akses komunikasi tersebut berupa tidak adanya jaringan telekomunikasi atau sinyal pada telepon genggam ataupun akses internet.

Penyebab terjadinya tidak terjangkaunya jaringan telekomunikasi dan internet tersebut dikarenakan lokasi Dusun Giriloyo dan Dusun di sekitarnya berbentuk seperti mangkok atau berada di antara pegunungan yang mengelilinginya. Masyarakat sekitar jika akan menggunakan perangkat telekomunikasi harus beralih posisi menuju ke Balai Desa Wukirsari atau menuju ke Kecamatan Imogiri. Hal ini terjadi karena lokasi Balai Desa Wukirsari dan Kecamatan Imogiri berada di jalan utama Jogja-Imogiri. Selain itu, lokasi tersebut berada di dataran rendah yang di sekeliling terdapat tower telekomunikasi atau penyedia jasa telekomunikasi.

Kelima, kurangnya kesadaran dan ketertarikan generasi muda untuk membatik. Kelompok batik tulis Sekar Arum yang berada di Dusun Giriloyo, Desa Wukirsari, Kecamatan Imogiri, Kabupaten Bantul merupakan salah satu kelompok batik yang memiliki anggota terbanyak. Anggota kelompok batik tulis Sekar Arum mayoritas adalah perempuan yang merangkap sebagai ibu rumah tangga. Keanggotaan di kelompok batik tulis Sekar Arum merupakan salah satu dilema yang dihadapi oleh kelompok. Mayoritas anggota tidak menurunkan ilmu dan ketrampilan kepada anak-anaknya. Hal ini yang menjadi permasalahan serius. Banyak anggota kelompok batik tulis berharap bahwa anak-anak mereka memiliki kerja di kota ataupun di luar provinsi. Tidak adanya regenerasi ketrampilan dan kemampuan dalam membatik menjadi kendala tersendiri dalam keberlangsungan usaha bersama kelompok batik ini. Kendala tidak hanya dalam keberlangsungan usaha bersama saja, tetapi kendala akan berdampak besar pada eksistensi dan keberadaan batik tulis Giriloyo khususnya di Sekar Arum. Batik tulis Giriloyo merupakan salah satu hasil budaya yang wajib dijaga eksistensinya. Tidak adanya regenerasi terhadap proses dan pembuatan batik tulis di daerah ini menjadikan hilang atau punahnya batik tulis Giriloyo.

\section{Upaya Mengatasi Kendala}

Beberapa upaya yang dilakukan oleh kelompok batik Sekar Arum dalam menanggulangi permasalahan tersebut dijelaskan di bawah ini.

Pertama, pengoptimalan pemasaran berbagai produk batik tulis Giriloyo. Pengoptimalan pemasaran dilakukan oleh berbagai kelompok batik tulis yang ada di Dusun Giriloyo melalui kerjasama antar kelompok, melalui kerjasama dengan Dinas dan Instansi pemerintah khususnya dalam pendampingan usaha mikro, kecil, menengah, serta menjalin kerjasama dengan pihak swasta dalam berbagai hal khususnya pengembangan wilayah wisata desa yang bersumber dari CSR perusahaan swasta.

Pengembangan pemasaran yang dilaksanakan oleh kelompok batik tulis di Dusun Giriloyo termasuk di dalamnya Kelompok Batik Tulis Sekar Arum. Pengembangan pemasaran yang dilakukan berupa pengembangan produk, yang tidak hanya tertuju pada target penjualan kain batik tulis saja, tetapi juga pemanfaatan wilayah desa yang asri untuk membuat desa budaya. Desa budaya adalah wahana sekelompok manusia yang melakukan aktivitas budaya yang mengekspresikan sistem kepercayaan, 
sistem kesenian, sistem mata pencaharian, sistem teknologi, sistem komunikasi, sistem sosial, dan sistem lingkungan, tata ruang, dan arsitektur dengan mengaktualisasikan kekayaan potensinya dan mengkonservasinya dengan seksama atas kekayaan budaya yang dimilikinya, terutama yang tampak pada adat dan tradisi, seni pertunjukan, kerajinan, dan tata ruang dan arsitektural. Berlakunya desa budaya tersebut, menjadikan Dusun Giriloyo menjadi salah satu destinasi alternatif wisata budaya yang berbasis kehidupan desa dengan pengalaman membatik dan hidup selayaknya sebagai pengrajin batik.

Kedua, pendampingan pembuatan sistem laporan keuangan. Laporan keuangan merupakan salah satu hal yang penting dalam pengembangan usaha. Laporan keuangan juga dapat dijadikan sebagai salah satu syarat untuk pengajuan kredit di lembaga keungan. Mengatasi kendala mengenai pembuatan laporan keuangan, pihak kelompok batik tulis Sekar Arum telah mengajak berbagai pihak untuk memberikan penyuluhan dan bimbingan dalam pembuatan laporan keuangan. Berbagai pihak yang telah dimintai bantuan untuk membimbing pembuatan laporan keuangan oleh kelompok batik tulis Sekar Arum yaitu pihak universitas atau akademisi, pihak Pemerintah Daerah, ataupun pihak lembaga keuangan.

Ketiga, menjalin komunikasi dengan berbagai pihak untuk perbaikan aksesibilitas. Akses jalan merupakan salah satu hal terpenting untuk mendukung terwujudnya kesetaraan pembangunan ekonomi kemasyarakatan. Akses jalan yang ada untuk menuju ke Dusun Giriloyo merupakan jalan yang telah dibangun sejak pertama kali pengaspalan jalan. Jalan tersebut saat ini kondisinya memprihatinkan, terlebih terkena imbas gempa Jogja. Kondisi jalan yang ada di Dusun Giriloyo saat ini penuh dengan lubang dan tidak rata. Selain itu lebar jalan tidak memungkinkan untuk dilewati oleh kendaraan besar. Mengatasi permasalahan ini, pihak dusun dan Desa Wukirsari menjalin komunikasi yang intens ke pihak Pemerintah Kabupaten Bantul. Namun demikian, sampaii saat ini, usaha tersebut belum membuahkan hasil yang optimal. Pihak Pemerintah Kabupaten Bantul ataupun Pemerintah Daerah lebih berfokus pada pengembangan potensi budaya di wilayah setempat.

Keempat, menjalin komunikasi intens dengan provider dan Pemerintah Kabupaten. Komunikasi merupakan salah satu hal terpenting di era digitalisasi. Berbagai aspek kehidupan telah merambah aspek digitalisasi termasuk aspek bisnis dan UMKM. Komunikasi digital yang terjadi di era globalisasi saat ini telah dimanfaatkan untuk persaingan usaha. Komunikasi digital yang digunakan berupa pemanfaatan jaringan internet dan jaringan komunikasi telepon selular. Lokasi Dusun Giriloyo yang terletak di lereng perbukitan menjadi kendala untuk jaringan komuniikasi. Berdasarkan hal tersebut, beberapa upaya telah dilakukan oleh masyarakat, pengurus desa, dan pengurus kecamatan, yaitu menjalin komunikasi dengan pihak penyedia jasa komunikasi baik swasta ataupun negeri. Selain menjalin komunikasi oleh pihak penyedia jasa komunikasi, juga dilakukan audiensi serta permohonan kepada pemerintah Kabupaten Bantul untuk memediasi terwujudnya harapan masyarakat berupa pembangunan tower jaringan telekomunikasi. Jaringan telekomunikasi tersebut hendak dimanfaatkan untuk pengembangan bisnis 
serta usaha masyarakat, termasuk kelompok batik tulis Sekar Arum dalam upaya mencapai kesejahteraan keluarga.

Kelima, kerjasama dengan pemerintah untuk pendidikan dan proses regenerasi. Persoalan yang paling mendasar dalam keberlangsungan dan eksistensi batik tulis Giriloyo adalah regenerasi pembatik tulis Giriloyo, baik terkait dengan pengetahuan tentang batik maupun kecakapan membatik itu sendiri. Kendala mengenai keberlanjutan batik Giriloyo tersebut telah menjadi pembahasan bersama antara pengusaha batik Giriloyo yang tergabung dalam kelompok-kelompok batik dengan sesepuh Desa Wukirsari, sesepuh Dusun Giriloyo, Pemerintah Desa Wukirsari, Pemerintah Kecamatan Imogiri, Pemerintah Kabupaten Bantul, Pemerintah Daerah Istimewa Yogyakarta yang telah menjadikan kawasan tersebut menjadi kawasan desa wisata dan budaya.

Pembahasan yang telah dilakukan oleh tokoh-tokoh kelompok batik tulis Giriloyo, termasuk kelompok batik tulis Sekar Arum, berkaitan dengan pendokumentasian batik tulis Giriloyo. Pendokumentasian batik tulis Giriloyo tersebut dilakukan untuk menjadi sumber wawasan dan pengetahuan bagi generasi mendatangyang akan memperdalampengetahuan mengenai batik Giriloyo. Lebih lanjut, mereka berusaha mengajak dan menggandeng Pemerintah Kabupaten Bantul dan Pemerintah Daerah Istimewa Yogyakarta untuk mengadakan pelatihan-pelatihan mengenai pembuatan proses batik tulis Giriloyo. Pelatihan-pelatihan yang diadakan oleh pihak Pemerintah Kabupaten dan Pemerintah Daerah Istimewa Yogyakarta dimaksudkan untuk terlibat secara nyata dalam proses regenerasi pembatik-pembatik yang ada di Giriloyo.
Penjelasan kualitatif seperti diuraikan di atas, dalam penelitian ini secara metodis dilengkapi dengan penjelasan kuantitatif. Untuk itu perlu dilakukan uji validitas dan uji reliabilitas sebagaimana diuraikan dibawah ini.

\section{Uji Validitas dan Uji Reliabilitas}

Uji validitas dan reliabilitas kuesioner diperlukan untuk memastikan bahwa kuesioner yang digunakan dalam penelitian mampu mengukur variabel penelitian dengan baik.

\section{Uji Validitas}

Uji Validitas Item adalah uji statistik yang digunakan guna menentukan seberapa valid suatu item pertanyaan mengukur variabel yang diteliti. Uji Validitas Item atau butir tersebut dilakukan dengan menggunakan software SPSS ver. 16.0 for Windows, melalui Uji Korelasi Pearson Product Moment. Pada uji ini, setiap item dalam variabel $\mathrm{X}$ dan variabel Y diuji relasinya dengan skor total variabel yang dimaksud (David: 2002).

Lebih lanjut, sebuah item sebaiknya memiliki korelasi (r) dengan skor total masingmasing variabel $\geq 0,25$. Item yang mempunyai korelasi (r) hitung $<0,25$ disingkirkan, sebagai akibat tidak terukur secara sama dengan yang dimaksud oleh skor total skala, dan lebih jauh lagi tidak memiliki kontribusi dengan pengukuran seseorang jika bukan malah mengacaukan (Marguerite, 2006).

Uji validitas yang dilakukan terhadap variabel X (Pendapatan Keluarga) dapat dilihat pada tabel 5.

Berdasarkan parameter bahwa nilai r Tot $X$ hitung $>$ r Tot. $X$ tabel maka data dinyatakan memiliki validitas. Nilai Tot $\mathrm{X}$ untuk jumlah sampel 30 maka nilai $r$ tabel yaitu 0,3601 . 
Arif NursaId dan Armaidy Armawi -- Peran Kelompok Batik Tulis Giriloyo Dalam Mendukung

Ketahanan Ekonomi Keluarga (Studi Di Dusun Giriloyo, Desa Wukirsari, Kecamatan Imogiri, Kabupaten Bantul, Daerah Istimewa Yogyakarta)

Tabel 5. Uji Validitas Variabel X (Pendapatan Keluarga)

\begin{tabular}{|c|c|c|c|c|c|c|c|c|c|c|c|}
\hline \multicolumn{12}{|c|}{ Correlations } \\
\hline & & $\mathrm{X} 1$ & $\mathrm{X} 2$ & $\mathrm{X} 3$ & $\mathrm{X} 4$ & $\mathrm{X} 5$ & $\mathrm{X} 6$ & $\mathrm{X7}$ & $\mathrm{X} 8$ & $\mathrm{X} 9$ & Tot. X \\
\hline \multirow{5}{*}{$\mathrm{X} 1$} & Pearson Correlation & 1 & ,284 & ,294 & ,273 &,- 093 &,- 043 &, 160 & ,235 & ,114 &, $416^{*}$ \\
\hline & Sig. (2-tailed) & & ,128 &, 115 & 144 &, 625 & 823 & ,397 & ,211 & ,549 &, 022 \\
\hline & $\mathrm{N}$ & 30 & 30 & 30 & 30 & 30 & 30 & 30 & 30 & 30 & 30 \\
\hline & Pearson Correlation & ,284 & 1 &, $606^{* *}$ &, 087 &,- 223 & ,291 & ,284 & ,174 & ,350 &, $606^{* *}$ \\
\hline & Sig. (2-tailed) & , 128 & &, 000 & ,649 &, 237 & ,119 & ,129 & ,358 &, 058 &, 000 \\
\hline \multirow[t]{3}{*}{$\mathrm{X} 2$} & $\mathrm{~N}$ & 30 & 30 & 30 & 30 & 30 & 30 & 30 & 30 & 30 & 30 \\
\hline & Pearson Correlation & ,294 &, $606^{* *}$ & 1 & ,140 &, 114 & ,404* & , 448* &, 160 & ,207 &, $713^{* *}$ \\
\hline & Sig. (2-tailed) &, 115 &, 000 & & ,460 &, 548 &, 027 &, 013 & ,400 & ,274 &, 000 \\
\hline \multirow[t]{3}{*}{$\mathrm{X} 3$} & $\mathrm{~N}$ & 30 & 30 & 30 & 30 & 30 & 30 & 30 & 30 & 30 & 30 \\
\hline & Pearson Correlation & ,273 & 087 &, 140 & 1 &, 141 &,- 020 & ,066 & ,293 & 024 &, $400^{*}$ \\
\hline & Sig. (2-tailed) & ,144 & ,649 & ,460 & & ,456 & ,915 &, 731 & ,116 & ,901 &, 029 \\
\hline \multirow[t]{3}{*}{$\mathrm{X} 4$} & $\mathrm{~N}$ & 30 & 30 & 30 & 30 & 30 & 30 & 30 & 30 & 30 & 30 \\
\hline & Pearson Correlation &,- 093 &,- 223 &, 114 & ,141 & 1 &, $412^{*}$ &, 158 &,- 128 & ,219 &, $382^{*}$ \\
\hline & Sig. (2-tailed) & ,625 &, 237 &, 548 & ,456 & &, 024 & ,404 &, 500 & ,246 &, 037 \\
\hline \multirow[t]{3}{*}{$\mathrm{X} 5$} & $\mathrm{~N}$ & 30 & 30 & 30 & 30 & 30 & 30 & 30 & 30 & 30 & 30 \\
\hline & Pearson Correlation &,- 043 & ,291 & ,404* &,- 020 &, $412^{*}$ & 1 &, 047 &,- 117 & ,341 &, $577^{* *}$ \\
\hline & Sig. (2-tailed) & 823 & ,119 &, 027 & ,915 &, 024 & & ,807 &, 537 &, 065 &, 001 \\
\hline \multirow[t]{3}{*}{ X6 } & $\mathrm{N}$ & 30 & 30 & 30 & 30 & 30 & 30 & 30 & 30 & 30 & 30 \\
\hline & Pearson Correlation &, 160 & ,284 & , 448* &, 066 & , 158 &, 047 & 1 & ,246 &, 314 &, $554^{* *}$ \\
\hline & Sig. (2-tailed) & ,397 & ,129 &, 013 &, 731 &, 404 &, 807 & & ,191 & ,091 &, 001 \\
\hline \multirow[t]{3}{*}{$\mathrm{X} 7$} & $\mathrm{~N}$ & 30 & 30 & 30 & 30 & 30 & 30 & 30 & 30 & 30 & 30 \\
\hline & Pearson Correlation & ,235 &, 174 &, 160 & ,293 &,- 128 &,- 117 & ,246 & 1 & , 190 & ,399* \\
\hline & Sig. (2-tailed) & ,211 & ,358 & ,400 & ,116 &, 500 &, 537 & ,191 & & ,313 & ,029 \\
\hline \multirow[t]{3}{*}{$\mathrm{X} 8$} & $\mathrm{~N}$ & 30 & 30 & 30 & 30 & 30 & 30 & 30 & 30 & 30 & 30 \\
\hline & Pearson Correlation &, 114 &, 350 & 207 &, 024 & ,219 &, 341 &, 314 & ,190 & 1 &, $606^{* *}$ \\
\hline & Sig. (2-tailed) &, 549 &, 058 & ,274 & ,901 & ,246 &, 065 & ,091 &, 313 & &, 000 \\
\hline \multirow[t]{2}{*}{ X9 } & $\mathrm{N}$ & 30 & 30 & 30 & 30 & 30 & 30 & 30 & 30 & 30 & 30 \\
\hline & Pearson Correlation &, $416^{*}$ &, $606^{* *}$ &, $713^{* *}$ &, $400^{*}$ & ,382* &, $577^{* *}$ &, $554^{* *}$ & ,399* &, $606^{* *}$ & 1 \\
\hline Tot. & Sig. (2-tailed) & ,022 &, 000 &, 000 & ,029 &, 037 &, 001 &, 001 & ,029 &, 000 & \\
\hline $\mathrm{X}$ & $\mathrm{N}$ & 30 & 30 & 30 & 30 & 30 & 30 & 30 & 30 & 30 & 30 \\
\hline
\end{tabular}

*. Correlation is significant at the 0.05 level (2-tailed).

**. Correlation is significant at the 0.01 level (2-tailed).

Sumber : Data Primer, 2016

Nilai $r$ tabel didapatkan dari hasil ketentuan umum mengenai validitas. Nilai $r$ hitung pada Tot X1 hingga Tot.X9 yaitu 0,416, 0,606, 0,713,0,400, 0,382, 0,577, 0,554, 0,399, 0,606 . Berdasarkan hasil tersebut maka $r$ hitung pada Tot X1 > r tabel, sehingga Tot X1 memiliki validitas

Uji validitas yang dilakukan terhadap variabel Y (Ketahanan Ekonomi Keluarga) dapat dilihat pada tabel 6 di bawah ini.

Tabel 6 di atas merupakan alat untuk menguji tingkat validitas kaitan antara pendapatan keluarga terhadap ketahanan ekonomi keluarga. Berdasarkan parameter bahwa nilai $r$ Tot $\mathrm{Y}$ hitung $>$ r Tot $\mathrm{Y}$ tabel maka data dinyatakan memiliki validitas. Nilai Tot $\mathrm{Y}$ untuk jumlah sampel 30 maka nilai $\mathrm{r}$ tabel, yaitu 0,3601 . Nilai $r$ hitung pada Tot Y1 hingga Tot.Y5 yaitu 0,839, 0,846, 0,849 $0,785,0,839$. Berdasarkan hasil tersebut maka $r$ hitung pada Tot $\mathrm{Y} 1>\mathrm{r}$ tabel, sehingga Tot Y1 memiliki validitas. 
Tabel 6. Uji Validitas Variabel Y (Ketahanan Ekonomi Keluarga)

\begin{tabular}{|c|c|c|c|c|c|c|c|}
\hline \multicolumn{8}{|c|}{ Correlations } \\
\hline & & $\mathrm{Y} 1$ & $\mathrm{Y} 2$ & Y3 & $\mathrm{Y} 4$ & Y5 & Tot.Y \\
\hline \multirow[t]{3}{*}{ Y1 } & Pearson Correlation & 1 &, $767^{* *}$ &, $552^{* *}$ &, $505^{* *}$ &, $617^{* *}$ &, $839^{* *}$ \\
\hline & Sig. (2-tailed) & &, 000 & ,002 &, 004 &, 000 &, 000 \\
\hline & $\mathrm{N}$ & 30 & 30 & 30 & 30 & 30 & 30 \\
\hline \multirow[t]{3}{*}{ Y2 } & Pearson Correlation &, $767^{* *}$ & 1 &, $594^{* *}$ &, $537^{* *}$ &, $567^{* *}$ &, $846^{* *}$ \\
\hline & Sig. (2-tailed) &, 000 & &, 001 & ,002 &, 001 &, 000 \\
\hline & $\mathrm{N}$ & 30 & 30 & 30 & 30 & 30 & 30 \\
\hline \multirow[t]{3}{*}{ Y3 } & Pearson Correlation &, $552^{* *}$ &, $594^{* *}$ & 1 &, $690^{* *}$ &, $714^{* *}$ &, $849^{* *}$ \\
\hline & Sig. (2-tailed) &, 002 &, 001 & &, 000 &, 000 &, 000 \\
\hline & $\mathrm{N}$ & 30 & 30 & 30 & 30 & 30 & 30 \\
\hline \multirow[t]{3}{*}{ Y4 } & Pearson Correlation &, $505^{* *}$ &, $537^{* *}$ &, $690^{* *}$ & 1 &, $616^{* *}$ &, $785^{* *}$ \\
\hline & Sig. (2-tailed) &, 004 & ,002 &, 000 & &, 000 &, 000 \\
\hline & $\mathrm{N}$ & 30 & 30 & 30 & 30 & 30 & 30 \\
\hline \multirow[t]{3}{*}{ Y5 } & Pearson Correlation &, $617^{* *}$ &, $567^{* *}$ &, $714^{* *}$ &, $616^{* *}$ & 1 &, $839^{* *}$ \\
\hline & Sig. (2-tailed) &, 000 &, 001 &, 000 &, 000 & &, 000 \\
\hline & $\mathrm{N}$ & 30 & 30 & 30 & 30 & 30 & 30 \\
\hline \multirow[t]{3}{*}{ Tot.Y } & Pearson Correlation &, $839^{* *}$ &, $846^{* *}$ &, $849^{* *}$ &, $785^{* *}$ &, $839^{* *}$ & 1 \\
\hline & Sig. (2-tailed) &, 000 &, 000 &, 000 &, 000 &, 000 & \\
\hline & $\mathrm{N}$ & 30 & 30 & 30 & 30 & 30 & 30 \\
\hline
\end{tabular}

Sumber : Data Primer, 2016

\section{Uji Reliabilitas}

Reliabilitas item diuji dengan melihat Koefisien Alpha melalui Reliability Analysis dengan SPSS ver. 16.0 for Windows Melalui analisis tersebut dapat dilihat nilai AlphaCronbach untuk reliabilitas keseluruhan item dalam satu variabel. Agar lebih teliti, dengan menggunakan SPSS tersebut, juga dilihat kolom Corrected Item Total Correlation.

Nilai tiap-tiap item sebaiknya $\geq 0.3601$ sehingga membuktikan bahwa item tersebut dapat dikatakan punya reliabilitas konsistensi internal. Item-item yang punya koefisien korelasi $<0.3601$ disingkirkan, kemudian Uji Reliabilitas item diulang dengan tidak menyertakan item yang tidak reliabel tersebut. Demikian terus dilakukan hingga Koefisien Reliabilitas masingmasing item adalah $\geq 0.3601$ (John, 2006).

Suatu instrument dikatakan reliabel apabila mampu mengukur apa yang diinginkan dan mengungkapkan data dari variabel yang diteliti secara tepat. Singarimbun dan Effendi (1997) menyatakan bahwa reliabilitas menunjukkan sejauh mana alat ukur itu mampu mengukur apa yang ingin diukur. Dalam pengujian statistik Alpha-Cronbach, instrumen dikatakan reliabel untuk mengukur variabel jika memiliki nilai alpha lebih besar dari 0,60, dan dianggap tidak reliabel jika mempunyai nilai di bawah 0,60 (Ghosali: 2002; Ronny Kountur: 2003),

Uji reliabilitas untuk variabel $\mathrm{X}$ (Pendapatan Keluarga) dapat dilihat dalam tabel 7.

Tabel 7 menunjukkan bahwa berdasar hasil olah data dari 30 sampel, nilai Alpha Cronbach yang dihasilkan sebesar 0,651 . Nilai Alpha-Cronbach tersebut melebihi nilai alpha 0,60 , sehingga dapat dipastikan bahwa data variabel $\mathrm{X}$ adalah reliabel.

Uji reliabilitas untuk variabel $\mathrm{Y}$ ((Ketahanan Ekonomi Keluarga) dapat dilihat dalam tabel 8 . 
Arif NursaId dan Armaidy Armawi -- Peran Kelompok Batik Tulis Giriloyo Dalam Mendukung Ketahanan Ekonomi Keluarga (Studi Di Dusun Giriloyo, Desa Wukirsari, Kecamatan Imogiri, Kabupaten Bantul, Daerah Istimewa Yogyakarta)

Tabel 7.

Uji Reliabilitas Variabel X (Pendapatan Keluarga) Case Processing Summary

\begin{tabular}{llrr}
\hline \multicolumn{3}{c}{} & \multicolumn{2}{c}{$\%$} \\
\hline Cases & Valid & 30 & 100,0 \\
& Excluded $^{\mathrm{a}}$ & 0 &, 0 \\
\cline { 2 - 4 } & Total & 30 & 100,0 \\
\hline
\end{tabular}

a. Listwise deletion based on all variables in the procedure.

Reliability Statistics

\begin{tabular}{|c|c|}
\hline Cronbach's & \\
\hline Alpha & $\mathrm{N}$ of Items \\
\hline, 651 & 9 \\
\hline
\end{tabular}

Sumber : Data Primer, 2016

Tabel 8.

Uji Reliabilitas Variabel Y (Ketahanan Keluarga) Case Processing Summary

\begin{tabular}{llrr}
\hline & \multicolumn{2}{r}{$\%$} \\
\hline Cases & Valid & 30 & 100,0 \\
& Excluded $^{\text {a }}$ & 0 &, 0 \\
& Total & 30 & 100,0 \\
\hline
\end{tabular}

a. Listwise deletion based on all variables in the procedure.

Reliability Statistics

\begin{tabular}{|c|c|}
\hline $\begin{array}{c}\text { Cronbach's } \\
\text { Alpha }\end{array}$ & $\mathrm{N}$ of Items \\
\hline, 887 & 5 \\
\hline
\end{tabular}

Sumber : Dara Primer, 2016.

Tabel 8 menunjukkan bahwa berdasar hasil olah data dari 30 sampel, nilai Alpha Cronbach yang dihasilkan sebesar 0,887 . Nilai Alpha-Cronbach tersebut melebihi nilai alpha 0,60, sehingga dapat dipastikan bahwa data variabel $Y$ adalah reliabel.

Berdasarkan hasil uji validitas dan uji realibilitas tersebut di atas dapat dikatakan bahwa data untuk masing-masing variabel adalah valid dan reliabel. Oleh sebab itu, penelitian ini dapat dilanjutkan untuk mengetahui uji yang lain, yaitu dengan analisis regresi.

\section{Pengaruhna Terhadap Ketahanan Ekonomi Keluarga}

Ketahanan ekonomi keluarga diukur sesuai dengan indikator yang telah ditetapkan oleh Badan Pusat Statistik, Standar UMK, Peraturan Bupati No 21 A Tahun 2007 Tentang Indikator Kemiskinan Kabupaten Bantul, dan Bank Dunia. Ketahanan ekonomi keluarga tersebut sangat terkait dengan masalah kemiskinan, sebab sebuah keluarga yang mempunyai ketahanan berarti keluarga tersebut jauh dari kemiskian (Lemhannas, 1997). Profil kemiskinan secara keseluruhan dicirikan oleh pendapatan rendah, kondisi kesehatan buruk, pendidikan rendah, keahlian terbatas, akses terhadap tanah dan modal rendah, sangat rentan terhadap gejolak ekonomi, serta partisipasi rendah dalam proses pengambilan kebijakan.

Ketahanan ekonomi keluarga sesuai dengan masing-masing indikator tersebut dijelaskan di bawah ini.

Pertama, indikator Badan Pusat Statistik. Badan Pusat Statistik menetapkan delapan variabel yang dianggap layak dan operasional sebagai indikator untuk menentukan rumah tangga miskin, yaitu: (1). luas lantai per kapita, (2). jenis lantai, (3). air minum/ ketersediaan air bersih, (4). jenis jamban/ wc, (5). kepemilikan aset, (6). pendapatan per bulan, (7). pengeluaran, khususnya prosentase pengeluaran untuk makanan, dan (8). konsumsi lauk pauk (BPS, 2008: 121) Berdasarkan data penelitian yang ada dapat dikatakan bahwa anggota kelompok batik tulis Sekar Arum termasuk ke dalam kelompok penduduk tidak miskin. 
Kedua, indikator sesuai standar UMK. Upah Minimum Kabupaten (UMK) yang diusulkan Kepala Dinas Tenaga Kerja dan Transmigrasi (Disnakertrans) kepada Gubernur Daerah Istimewa Yogyakarta mengikuti PP Nomor 78/ 2015 Tentang Pengupahan Kabupaten Bantul yaitu sebesar Rp 1.297.700. Berdasar laporan keuangan seluruh anggota kelompok Sekar Arum dapat dikatakan bahwa total pendapatan yang ada mencapai Rp. 62.610.000,-. Pendapatan tersebut terdiri dari dua sumber yaitu; 1). Pendapatan dari ibu rumah tangga. Pendapatan ibu rumah tangga tersebut berasal dari proses hasil membatik sebesar Rp. 12.000.000,-, sehingga rata-rata pendapatan sebesar Rp. 400.000,-. Rata-rata pendapatan tersebut jauh dari UMK Kabupaten Bantul yang telah ditetapkan. 2). Pendapatan utama keluarga berasal dari usaha kepala rumah tangga, dengan jumlah keseluruhan sebesar Rp. 44.060.000,- Pendapatan utama keluarga tersebut memiliki rata-rata Rp. 1.468.700,Lebih lanjut, kedua pendapatan tersebut dijadikan sistem kolektif dalam sebuah keuangan keluarga, sehingga didapatkan rata-rata pendapatan keluarga sebesar Rp. 2.087.000,- Rata-rata pendapatan tersebut telah mencapai nilai UMK sebesar Rp 1.297.700,-. Dengan pendapatan tersebut, keluarga anggota kelompok Sekar Arum dapat memenuhi berbagai kebutuhan, yaitu kebutuhan fisik, kebutuhan sosial, dan kebutuhan jiwa.

Pemenuhan kebutuhan fisik adalah pemenuhan kebutuhan yang berorientasi pada kebutuhan jasmani, yaitu untuk keperluan makan, minum dan sejenisnya. Pemenuhan kebutuhan sosial adalah pemenuhan kebutuhan yang bersifat sosial, seperti nyumbang, iuran dusun, iuran arisan bapak-bapak, arisan ibu-ibu, upacara adat, dan lain sebagainya. Pemenuhan kebutuhan jiwa adalah pemenuhan kebutuhan yang berfungsi untuk menenangkan hati dan pikiran. Pemenuhan ini bersifat tersier, tetapi tidak bisa dipisahkan dalam kehidupan masyarakat saat ini, seperti rekreasi, kegiatan agama dan ibadah.

Ketiga, indikator Peraturan Bupati Nomor 21 A Tahun 2007 Tentang Indikator Keluarga Miskin Kabupaten Bantul. Indikator Keluarga Miskin Kabupaten Bantul tersebut ditunjukkan oleh aspek pangan, aspek sandang, dan aspek papan.

Terkait dengan aspek pangan, keluarga anggota kelompok Sekar Arum telah dapat memenuhinya, dengan mengkonsumsi makanan tiga kali sehari, diselangi oleh santapan sore dan minum teh atau kopi yang telah menjadi kebiasaan warga setempat. Terkait dengan aspek sandang, keluarga anggota kelompok Sekar Arum juga telah dapat memenuhinya, karena anggota keluarga adalah pembuat bahan sandang. Sandang yang ada di rumah merupakan sandang keseharian dan sandang untuk keperluan khusus. Jumlah sandang yang dimiliki oleh keluarga anggota kelompok lebih dari enam stel pakaian. Terkait dengan aspek papan, keluarga anggota kelompok Sekar Arum dikatakan tidak miskin sebab kebanyakan tempat tinggal berdinding papan kayu jati dan bambu anyam. Properti ini digunakan untuk keperluan wisata dan mempertahankan bentuk asli rumah tradisional yaitu limasan. Keluarga anggota kelompok Sekar Arum tidak memiliki rumah yang beratap rumbia. Hal ini membuktikan bahwa keluarga anggota kelompok tidak tergolong keluarga miskin.

Selain ketiga aspek penentu kemiskinan tersebut, terdapat aspek pendukung kemiskinan, 
yaitu aspek kesehatan, aspek pendidikan, aspek kekayaan, akses air bersih, akses listrik, dan aspek jumlah anggota / jiwa dalam KK. Terkait dengan aspek kesehatan, seluruh warga Dusun Giriloyo mendapat jaminan kesehatan dari pemerintah. Akses menuju layanan kesehatan tidak terlalu sulit untuk dijangkau oleh masyarakat termasuk keluarga anggota kelompok Sekar Arum. Aspek pendidikan bagi keluarga anggota kelompok Sekar Arum tidak menjadi masalah sebab pembiayaan pendidikan warga telah ditanggung oleh pemerintah melalui dana BOS dan berbagai pembiayaan lainnya. Bantuan pembiayaan ini sangat membantu keluarga anggota kelompok dalam menyekolahkan anggota keluarganya. Diperoleh informasi bahwa ada anak dari pengrajin batik yang menempuh pendidikan hingga jenjang sarjana. Aspek kekayaan merupakan salah satu aspek pendukung kemiskinan. Seseorang dikatakan miskin apabila jumlah kekayaan milik keluarga sangat sedikit dan tanah serta bangunan yang ditempati bukan milik sendiri. Berdasarkan data yang ada dapat dikatakan bahwa setiap keluarga anggota kelompok Sekar Arum memiliki aset yang berupa perhiasan, tabungan, dan kepemilikan tanah serta bangunan. Hal ini menunjukkan bahwa untuk aspek kekayaan keluarga anggota kelompok Sekar Arum tidak termasuk dalam kategori miskin. Terkait dengan akses air bersih, keluarga anggota kelompok Sekar Arum dapat diklasifikasikan ke dalam keluarga yang mampu, sebab setiap keluarga anggota kelompok Sekar Arum menggunakan beberapa alternatif untuk memenuhi kebutuhan air bersih, yaitu air yang berasal dari sumur, air PAM, atau membeli air untuk memenuhi kebutuhan air bersih. Terkait dengan akses terhadap listrik, seluruh keluarga anggota kelompok Sekar Arum telah mengakses listrik. Berkaitan dengan jumlah anggota KK, keluarga anggota kelompok Sekar Arum tidak tergolong dalam kelompok miskin. Hal ini berdasarkan pada jumlah ratarata anggota keluarga kelompok Sekar Arum yang berjumlah 4 orang. Berdasarkan beberapa aspek penentu dan aspek pendukung, maka dapat disimpulkan bahwa keluarga anggota kelompok Sekar Arum tidak terklasifikasikan sebagai keluarga miskin.

Keempat, indikator Bank Dunia. Bank Dunia mengukur kemiskinan dengan ukuran pengeluaran US\$ 1 (asumsi: setara dengan Rp 13.200,-) per hari per kapita yang didasarkan pada paritas daya beli (World Bank, 2005). Berdasarkan hasil penelitian yang ada dapat dikatakan bahwa total pengeluaran dalam laporan keuangan sederhana milik keluarga anggota kelompok Sekar Arum sebesar Rp 38.956.000,Berdasarkan total pendapatan dan pengeluaran, maka didapatkan sisa pendapatan dari seluruh anggota kelompok Sekar Arum sebesar Rp 23.654.000,- Rata-rata sisa pendapatan yang didapat setiap keluarga sebesar Rp. 788.400,-

Rata-rata pengeluaran masing-masing keluarga anggota kelompok Sekar Arum sebesar Rp. 1.298.500,-, yang merupakan akumulasi setiap bulan. Jika dikaitkan dengan indikator dari Bank Dunia, berdasarkan purchasing power parity dan dengan asumsi rata-rata anggota keluarga 3 orang, maka rata-rata pengeluaran keluarga anggota kelompok Sekar Arum sebesar Rp. 39.600,-. Berdasarkan indikator pengeluaran sebesar Rp 13.200,- tersebut di atas, maka pengeluaran harian keluarga anggota kelompok Sekar Arum berada di atas indikator kemiskinan dari Bank Dunia.

Berdasar uraian tersebut di atas dapat disimpulkan bahwa keluarga anggota kelompok 
Sekar Arum mempunyai ketahanan ekonom keluarga yang kuat. Untuk menegaskan kesimpulan tersebut di bawah ini diuraikan keterkaitan peran kelompok batik tulis Sekar Arum dengan ketahanan ekonomi keluarga dalam bentuk analisis regresi linear sederhana.

\section{Analisis Regresi Linear Sederhana}

Koefisien determinasi digunakan untuk mengetahui seberapa besar hubungan dari beberapa variabel dalam pengertian yang lebih jelas. Koefisien determinasi juga menunjukkan seberapa besar perubahan atau variasi suatu variabel bisa dijelaskan oleh perubahan atau variasi pada variabel yang lain (Santosa dan Ashari, 2005:125).

Hubungan antara variabel pendapatan anggota kelompok Sekar Arum dengan variabel ketahanan ekonomi keluarga dapat dilihat pada table 9 .

Berdasarkan tabel 9 regresi linier sederhana "Model Summary" tersebut dapat disimpulkan bahwa pendapatan anggota kelompok Sekar Arum berpengaruh sebesar 98 persen terhadap ketahanan ekonomi keluarga, sedangkan 2\% dipengaruhi variabel lain yang tidak diteliti. Karena nilai R Square di atas 5\% atau cenderung mendekati nilai 1 maka dapat disimpulkan kemampuan variabel independen dalam menjelaskan variasi variabel sangatlah kuat. Berdasarkan olah data tersebut dapat juga disimpulkan bahwa pendapatan anggota kelompok Sekar Arum berpengaruh kuat dalam mencapai ketahanan ekonomi keluarga.

Terkait dengan regresi linier sederhana tersebut perlu dilakukan uji t. Uji t tersebut digunakan untuk mengetahui variabel independen secara parsial berpengaruh nyata atau tidak terhadap variabel dependen. Derajat signifikansi yang digunakan adalah 0,05. Apabila nilai signifikan lebih kecil dari derajat kepercayaan maka diterima hipotesis alternatif yang menyatakan bahwa suatu variabel independen secara parsial mempengaruhi variabel dependen. Analisis uji t dapat dilihat dari tabel 10, Coefficients.

Tabel 9.

Regresi Linear Sederhana (Model Summary)

\begin{tabular}{|c|c|c|c|c|c|}
\hline Model & $\mathrm{R}$ & R Square & $\begin{array}{l}\text { Adjusted R } \\
\text { Square }\end{array}$ & $\begin{array}{l}\text { Std. Error of the } \\
\text { Estimate }\end{array}$ & Durbin-Watson \\
\hline 1 &, $990^{\mathrm{a}}$ & ,980 &, 980 & 1,931 & 1,222 \\
\hline \multicolumn{6}{|c|}{ a. Predictors: (Constant), X } \\
\hline \multicolumn{6}{|c|}{ b. Dependent Variable: Y } \\
\hline
\end{tabular}

Tabel 10 .

Coefficients

\begin{tabular}{|c|c|c|c|c|c|c|}
\hline \multirow[b]{2}{*}{ Model } & & \multicolumn{2}{|c|}{ Unstandardized Coefficients } & $\begin{array}{c}\text { Standardized } \\
\text { Coefficients }\end{array}$ & \multirow[b]{2}{*}{$\mathrm{t}$} & \multirow[b]{2}{*}{ Sig. } \\
\hline & & $\mathrm{B}$ & Std. Error & Beta & & \\
\hline 1 & (Constant) & $-11,086$ & 2,484 & & $-4,463$ &, 000 \\
\hline & $\mathrm{X}$ & 1,492 &, 040 & ,990 & 37,401 &, 000 \\
\hline
\end{tabular}

Sumber : Data Primer, 2016. 
Tabel 10 Coefficients menunjukkan bahwa pendapatan anggota kelompok Sekar Arum memiliki pengaruh terhadap ketahanan ekonomi keluarga. Terlihat nilai sig pada variabel $\mathrm{X}$ yaitu pendapatan anggota kelompok Sekar Arum adalah 0,000. Nilai sig lebih kecil dari nilai probabilitas 0,05 atau 5\%. Berdasarkan hasil tersebut maka dapat disimpulkan bahwa pendapatan ekonomi pengrajin batik tulis kelompok Sekar Arum berpengaruh positif terhadap ketahanan ekonomi keluarga.

Berdasarkan tabel 10 Coefficients di atas dapat dilihat pula persamaan regresi linear sederhana yang ada dalam penelitian ini, yaitu $y=a+b x$. Persamaan regresi liear sederhana tersebut dapat dilihat pada kolom Unstandardized Coefficients, tepatnya kolom B. Kolom B tersebut terdiri dari nilai Constant yaitu $-11,086$ dan nilai variabel $\mathrm{x}$ yaitu 1,492. Berdasarkan hasil tersebut didapatkan persamaan regresi linear berganda yaitu $\mathrm{y}=$ $-11,086+1,492 x$. Nilai beta pada variabel $x$ yaitu 0,990 atau $99 \%$. Hal ini menunjukkan dukungan uji t yang menjelaskan bahwa variabel $\mathrm{x}$, yaitu peran kelompok batik, berpengaruh secara signifikan terhadap variabel y, yaitu ketahanan ekonomi keluarga.

\section{SIMPULAN}

Berdasarkan penjelasan tersebut di atas, maka dapat ditarik simpulan sebagai berikut.

Pertama, kelompok batik tulis Sekar Arum di Dusun Giriloyo, Desa Wukirsari, Kecamatan Imogiri, Kabupaten Bantul memiliki peran dalam mencapai ketahanan ekonomi keluarga. Peran yang dicapai yaitu Kelompok batik tulis di Giriloyo sebagai obyek wisata alternatif dan tempat pendidikan serta kelompok batik sebagai jembatan kesejahteraan.
Kedua, beberapa kendala yang dialami oleh kelompok batik tulis Sekar Arum, Dusun Giriloyo, Desa Wukirsari, Kecamatan Imogiri, Kabupaten Bantul. Kendala adalah sistem pemasaran produk batik tulis yang belum optimal, sistem laporan keuangan yang kurang profesional, aksesibilitas yang kurang mendukung, ketersediaan jaringan komunikasi sangat minim, dan kurangnya kesadaran dan ketertarikan generasi muda untuk membatik.

Ketiga, berbagai upaya yang dilakukan untuk mengatasi kendala adalah pengoptimalan pemasaran berbagai produk batik tulis Giriloyo dengan bekerja sama dengan dinas dan instansi pemerintah; pendampingan pembuatan sistem laporan keuangan; menjalin komunikasi dengan berbagai pihak untuk perbaikan aksesibilitas; menjalin komunikasi intens dengan provider dan Pemerintah Kabupaten untuk menyediakan jaringan internet dan jaringan komunikasi; serta kerjasama dengan pemerintah untuk pendidikan dan proses regenerasi.

Keempat, kelompok batik tulis Sekar Arum di Dusun Giriloyo telah berhasil mewujudkan ketahanan ekonomi keluarga. Hal ini dapat dilihat dari berbagai macam indikator yang ada, yaitu indikator Badan Pusat Statistik, Standar UMK, Peraturan Bupati No 21 A Tahun 2007 tentang Indikator Kemiskinan Kabupaten Bantul., dan Bank Dunia. Berdasar indikator tersebut dapat ditunjukkan bahwa keluarga anggota kelompok batik tulis Sekar Arum tidak termasuk dalam keluarga miskin.

Selanjutnya, direkomendasikan hal-hal sebagai berikut.

Pertama, mengingat potensi wisata yang terdapat di Dusun Giriloyo Desa 
Wukirsari, pemerintah daerah hendaknya dapat menyediakan akses transportasi dan akses jalan yang sesuai dengan standar sebagai infrastruktur daerah wisata, sehingga dapat dijangkau oleh wisatawan.

Kedua, mengingat pangsa pasar yang cukup besar di Dusun Giriloyo Desa Wukirsari, hendaknya dilakukan koordinasi antara pemerintah daerah dan pihak swasta dalam pengadaan jaringan internet dan telekomunikasi, sehingga produk batik dari Dusun Giriloyo, Desa Wukirsari dapat dipasarkan melalui jaringan internet dan telekomunikasi tersebut.

\section{DAFTAR PUSTAKA}

Badan Pusat Statistik, 2008, Analisis dan Penghitungan Tingkat Kemiskinan Tahun 2008. Jakarta.

Creswell, 2009, Qualitative, Quantitative, and Mixed Methods Approaches 3rd Edition, California: Sage Publication

David D. Vaus, 2002, Analyzing Social Science Data: 50 Key Problems in Data Analysis, Thousand Oaks: Sage Publications.

Ghozali, Imam, 2002, Aplikasi Analisis Multivariate Dengan Program SPSS, Semarang, Badan Penerbit Universitas Diponegoro.

John W. Lounsbury, Lucy W.Gibson, Richard A. Saudargas, 2006, "Scale Development" dalam Frederick T.L. Leong and James T. Austin, The Psychology Research Handbook: A Guide for Graduate Students and Research Assistants, Thousand Oaks: Sage Publications, Inc.

Kountur, Ronny. 2003. Metodologi Penelitian. Jakarta: Penerbirt PPM

Lemhannas, 1997, Ketahanan Nasional, Jakarta: Balai Pustaka Lemhannas.

Marguerite G. Lodico, Dean T. Spaulding,
Katherine H. Voegtle, 2006, Methods in Educational Research: From Theory to Practice (San Fransisco: John Wiley \& Sons, Inc.

Santosa P. Budi dan Ashari, 2005, Analisis Statistik dengan Microsoft Exccel \& SPSS. Yogyakarta, Penerbit ANDI.

Singarimbun dan Effendi , 1995, Metode Penelitian Survei. Jakarta, LP3ES.

Sudijono, Suhartinah, 2006, "Pasang Surut Batik Tulis Tradisional Bantul, Studi Kasus Batik Tulis Imogiri Tahun 19701998”, dalam Patra-Widya Vol. 7 No. 3. September 2006. Yogyakarta: Balai Kajian Sejarah dan Nilai Tradisional Yogyakarta Sunarti, E., Syarief, H., Megawangi, R., Hardiansyah, Saefudin, A., dan Husaini, 2003, "Perumusan Ukuran Ketahanan Keluarga”, Media Gizi dan Keluarga, 27 (1): $1-11$

Tim Sanggar Batik Barcode, 2010, Batik: Mengenal Batik dan Cara Mudah Membuat Batik, Jakarta, Kata Buku.

World Bank, 2005, Indonesia: Gagasan untuk Masa Depan, Mendukung Usaha Kecil dan Menengah.

\section{Peraturan Perundangan}

Undang-Undang No. 10 tahun 1992 Tentang Perkembangan Kependudukan dan Perkembangan Keluarga Sejahtera

Peraturan Bupati Bantul Nomor 21 A Tahun 2007 Tentang Indikator Keluarga Miskin Kabupaten Bantul

Peraturan Pemerintah Nomor 78/2015 Tentang Pengupahan Kabupaten Bantul

\section{Wawancara}

1. Nur Ahmadi : Ketua Kelompok Batik Tulis 